\title{
Suitability and Carrying Capacity of Tourism Area in Joint Protection Zone, Wongsorejo Subdistrict, Banyuwangi District
}

\author{
Ervina Wahyu Setyaningrum ${ }^{1}$, Agustina Tri Kusuma Dewi ${ }^{1}$, Endang Dewi Masitoh ${ }^{2}$ \\ ${ }^{1}$ Department of Fisheries, Faculty of Agriculture and Fisheries, University of 17 Agustus 1945, Banyuwangi, Indonesia \\ ${ }^{2}$ Department of Flsheries, Faculty of Fisheries and Marine, University of Airlangga, Surabaya, Indonesia
}

\begin{abstract}
Coastal area of Banyuwangi district became coral reefs conservation zone to overcome the bombing impact which is often done by the fishermen. This area is managed by Banyuwangi community and called Joint Protection Zone. Aim of this research is to understand suitability and carrying capacity of Bangsring coastal area (Joint Protection Zone) and the research was done by using descriptive method. Method of collecting data is Line intercept transect (LIT). Data analysis stage covered suitability analysis of marine tourism area for snorkeling and diving purposes, carrying capacity analysis. The results show that the marine tourism area of Bangsring Joint Protection Zone is suitable for diving purpose with an area of $1.6 \mathrm{Ha}$ and for snorkeling purpose with an area of $1.7 \mathrm{Ha}$. Meanwhile, the carrying capacity for diving activity is 8 persons per day and for snorkeling activity is 34 persons per day. So it can be concluded that marine tourism area in the Bangsring Coast (Joint Protection Zone) is in a suitable condition for diving with area of 2,764 $\mathrm{Ha}$ and snorkeling with area of 2,764 Ha. Carrying capacity of marine tourism area in the Bangsring Coast (Joint Protection Zone) is 14 people/day for diving and 55 people/day for snorkeling.
\end{abstract}

Keywords: Area Suitability, Coastal, Coral Reef.

\section{INTRODUCTION}

Coastal area and small islands management as sustainable ecotourism areas need suitable ecological environment that support carrying capacity of the area and also increase tourism income as an application of a system [1]. Marine tourism development is efforts to develop and to utilize the appealing objects of coastal and marine areas such as the beauty of coastal areas, diversity of marine parks in the form of various flora and fauna like coral reefs and decorative fishes, and traditional cultures related to marine legends. Meanwhile, the objective is to improve societal and economic condition of coastal communities through sustainable utilization of coastal and marine area potential [2].

States that the sustainability of development based on the conservation of the natural environment has become an important part for tourism development, and is included in the concept of sustainable tourism development supported by three pillars of economy, social culture and environment [3]. The sustainable use of coastal and marine resources especially capture, cultivation and tourism become very important in a management effort. Efforts to utilize coastal resources optimally, sustainably and sustainably is a very urgent demands for the

Correspondence address:

Ervina Wahyu Setyaningrum

Email : ervinawahyu@untag-banyuwangi.ac.id

Address : Jl. Adi Sucipto 26 Tamanbaru, Banyuwangi 68416 great-prosperity of the people, especially to improve the welfare of fishermen and fish farmers [4].

Potential utilization of coastal and marine resources, not only in the fishery sector, but also in other economic sectors such as tourism, marine transportation and renewable energy. Currently the utilization of coastal and marine resources especially in conservation areas is still very limited [5].

Land suitability is the adaptability of a land for a particular purpose, through land value determination (class) and land use patterns linked to the area potential, thus, more directed land use along with its sustainability can be attempted [6].

Carrying capacity is a factor with major influence on development. In this context, carrying capacity is a widely used concept that encomppasses four aspect namely physical, production, ecological, and social carrying capacity [7]. In the other hand, ecological carrying capacity as the maximum density of fish a ecosystems can naturally support during the period minimum available habitat that effect to ecological process, species, population, or communities in the environment [8].

Therefore, the community of Bangsring coastal area (Joint Protection Zone) committed to developing the area into coral reefs conservation area and marine tourism destination of Banyuwangi District. Important factors to be 
reviewed by the government of Banyuwangi are optimization aspect of marine tourism development in Bangsring coastal area and sustainable development design in preserving coastal resources which suitable for the surrounding ecology and communities.

Banyuwangi Regency has a large enough natural tourism potential, one of them is coral reef. This potential is even greater if it is associated with the position of Banyuwangi, as the entrance area to Bali via land travel. When the tourism potential can be developed properly, other related industries will also develop well.

The purpose of the research is to determine suitability and carrying capacity of marine tourism areas on the Bangsring coastal area (Joint Protection Zone).

\section{MATERIAL AND METHOD}

Main focus of this research are coral reefs and decorative fishes in Joint Protection Zone of Bangsring, Wongsorejo Subdistrict, Banyuwangi. The method used in this research was descriptive method. Meanwhile, collection data covered observation and direct sighting of research area that had been divided by transect lines. Research materials covered coral reefs diversity within the area of transects, and factors that affecting coral reefs growth such as temperature, clarity, $\mathrm{pH}$, salinity and current speed. Observations were done by identifying species and distribution of coral reefs within the area of transects, and at last, the results were converted into percentage.

\section{Coral Reefs Analysis}

Analysis method that used to determine coral reefs condition was Line Intercept Transect (LIT) method. Then, the coral reefs closure data were categorized based on Minister Decree of Ministry of Environment Number 4, 2001, about standard criteria for coral reefs damage, which are coral reefs closure of $0-24.9 \%$ (damaged), $25-49.9 \%$ (fair), $50-74.9 \%$ (good), and $75-100 \%$ (very good). This method used coral reefs covering area data as the main input. Covering percentage of coral reefs is percentage of area which covered by coral reefs. This parameter obtained from measuring the intercept of coral reefs colony on the transect line. Therefore, the formulation to calculate covering percentage [9] is:

\section{$\sum$ intercept length of coral reefs colony $\times 100 \%$ length of transect}

\section{Marine Tourism Suitability Analysis}

Suitability study of marine tourism suitability for diving purposes considers five parameters with four assessment classifications, which are waters clarity, coral reefs community covering area, type of lifeform, current speed of water, and coral reefs depth.

Meanwhile, suitability study of marine tourism for snorkeling purpose considers six parameters with four assessment classifications which are waters clarity, coral reefs community covering area, type of lifeform, current speed of water, coral reefs depth, and flat coral reefs width, refer to tables 1 and table 2 (Yulianda, 2007).

Tourism Suitability Index (Analisa Indeks Kesesuaian Wisata, IKW) analysis is the continuation of snorkeling and diving tourism suitability matrix that combined with Geographic Information System (GIS).

Table 3. Tourism Suitability Index in Diving Tour [10].

\begin{tabular}{llc}
\hline No. & \multicolumn{1}{c}{ Category } & Suitability Grade (\%) \\
\hline 1 & S1(Suitable) & $\geq 83-100$ \\
2 & S2(Conditionally Suitable) & $\geq 50-<83$ \\
3 & N (Not Suitable) & $<50$ \\
\hline
\end{tabular}

Table 1. Marine Tourism Suitability Matrix in Diving Tour Category.

\begin{tabular}{|c|c|c|c|c|c|c|c|c|c|c|}
\hline No. & Parameter & Value & $\begin{array}{c}\text { S1 } \\
\text { Category }\end{array}$ & Score & $\begin{array}{c}\text { S2 } \\
\text { Category }\end{array}$ & Score & $\begin{array}{c}\text { S3 } \\
\text { Category }\end{array}$ & Score & $\begin{array}{c}\mathbf{N} \\
\text { Category }\end{array}$ & Score \\
\hline 1 & Water brightness (\%) & 5 & $>80$ & 4 & $50-80$ & 3 & $20-<50$ & 2 & $<20$ & 1 \\
\hline 2 & Coral reefs coverage (\%) & 5 & $>75$ & 4 & $>50-75$ & 3 & $25-50$ & 2 & $<25$ & 1 \\
\hline 3 & Life form tyoe & 4 & $>12$ & 4 & $>7-12$ & 3 & $4-7$ & 2 & $<4$ & 1 \\
\hline 4 & Coral fish species & 4 & $>100$ & 4 & $50-100$ & 3 & $20-<50$ & 2 & $<20$ & 1 \\
\hline 5 & Current velocity (m/dt) & 3 & $0-15$ & 4 & $>15-30$ & 3 & $>30-50$ & 2 & $>50$ & 1 \\
\hline \multirow[t]{2}{*}{6} & Coral reefs depth (m) & 3 & $6-15$ & 4 & $>15-20$ & 3 & $>20-30$ & 2 & $>30$ & 1 \\
\hline & & & & & $3-<6$ & & & & $<3$ & \\
\hline
\end{tabular}

Source: Yulianda (2007). 
Table 2. Marine Tourism Suitability Matrix in Snorkeling Tour Category.

\begin{tabular}{|c|c|c|c|c|c|c|c|c|c|c|}
\hline No. & Parameter & Value & $\begin{array}{c}\text { S1 } \\
\text { Category }\end{array}$ & Score & $\begin{array}{c}\text { S2 } \\
\text { Category }\end{array}$ & Score & $\begin{array}{c}\text { S3 } \\
\text { Category }\end{array}$ & Score & $\begin{array}{c}\mathbf{N} \\
\text { Category }\end{array}$ & Score \\
\hline 1 & Water brightness (\%) & 5 & 100 & 4 & $80-<100$ & 3 & $20-<80$ & 2 & $<20$ & 1 \\
\hline 2 & Coral reefs coverage (\%) & 5 & $>75$ & 4 & $>50-75$ & 3 & $25-50$ & 2 & $<25$ & 1 \\
\hline 3 & Life form type & 4 & $>12$ & 4 & $>7-12$ & 3 & $4-7$ & 2 & $<4$ & 1 \\
\hline 4 & Coral fish species & 4 & $>50$ & 4 & $30-50$ & 3 & $10-<30$ & 2 & $<10$ & 1 \\
\hline 5 & Current velocity $(\mathrm{m} / \mathrm{dt})$ & 3 & $0-15$ & 4 & $>15-30$ & 3 & $>30-50$ & 2 & $>50$ & 1 \\
\hline 6 & Coral reefs depth (m) & 3 & $1-3$ & 4 & $>3-6$ & 3 & $>6-10$ & 2 & $>30$ & 1 \\
\hline 7 & Coral reefs area (m) & 3 & $>500$ & 4 & $>100-500$ & 3 & $20-100$ & 2 & $<20$ & 1 \\
\hline
\end{tabular}

Source: Yulianda (2007).

\section{Carrying Capacity Analysis}

Carrying capacity (Daya Dukung Kawasan, DDK) is maximum amount of visitors that can be accomodated by an area without occuring any bad impacts to environment and the visitors [10].

$D D K=K\left(L_{p} W_{t} / L_{t} W_{p}\right)$

Note:

DDK = Carrying capacity

$\mathrm{K}=$ = Maximum visitors per unit area

$\mathrm{Lp} \quad=$ Area or length of area that available

Lt $\quad=$ Area for specific category

$\mathrm{Wt} \quad=$ Available time of visit in one day

$\mathrm{Wp}=$ Times spent by visitors for specific activity

\section{RESULT AND DISCUSSION}

Coral Reefs in Joint Protection Zone of Bangsring Coastal Area

The ecosystem in Joint Protection Zone of Bangsring (coastal area of Kampe) is dominated by coral reefs. In this research, the data were gathered from three locations which decided based on recommendation of the local community who did several conservation works like coral reefs transplantation. The analysis results were:

- Location A: coral reefs covering area were 51\%.

- Location B: coral reefs covering area were $50 \%$.

- Location C: coral reefs covering area were $50.5 \%$.

The research locations were close to each other, however, there were difference in characteristics. For instance, location A located north of Bangsring which was planted by fish apartment that helped soft corals growth. At the same time, location B located south of Bangsring which can be found a wide area of coral reefs covering towards the open water, although in location $A$ the covering area was much wider with more diverse lifeforms. Meanwhile, characteristics of location $\mathrm{C}$ were much different compared to the previous two. The depth in location C was about 1.5 to 3.5 meter especially in the ebb phase which made it easy for beginner visitors to have snorkeling activities. Location $\mathrm{C}$ was set as the focal point of protection zone because in this area often occured fishermen's activities that involving the use of potassium which damaged the surrounding coral reefs and fishes community. After realizing the impacts, Samudera Bhakti group (fishermen community of Bangsring) which helped by several NGOs and educational institutions assigned location $\mathrm{C}$ as the focal point of protection zone that can be used only for conservation and educational activities, and forbidding any exploitation activities.

Compared to previous condition, coral reefs were found rapidly growth lately in the Joint Protection Zone. Various coral reefs type can be found which were Acropora sp. that dominating location A, B, and C, and Montastrea sp., Hydnophora sp., Montipora sp., Goniopora columna, and Oxupora crassispinosa in location A and $B$. In location $C$, many coral reefs were found different compared to location $A$ and $B$, which were Montipora foliosa Porites stephensoni, Heliofungia actiniformis, and Pleslastrea versipora. Acropora sp. became the most dominating coral reef in the three locations because its transplantation was the easiest and cheapest compared to other coral reefs. Moreover, Acropora sp. has low mortality risk because its high resistance of strong current.

According to Minister Decree of Ministry of Environment Number 4, 2001 about standard criteria for coral reefs damage, the coral reefs covering area of Bangsring Joint Protection Zone can be categorized as a good condition in general. This fact showed that local community can be responsible for organizing their environment. The environment that previously damaged because of coral reefs and decorative fishes exploitation can be restored by assigning Bangsring as Joint Protection Zone as the proof of local community's commitment. 
Table 4. Marine Tourism Suitability Matrix in Diving Tour Category of Bangsring Coast Joint Protection Zone.

\begin{tabular}{|c|c|c|c|c|}
\hline \multirow{2}{*}{\multicolumn{2}{|c|}{ Parameter }} & \multicolumn{3}{|c|}{ Station } \\
\hline & & A & B & C \\
\hline \multirow{5}{*}{ Water Brightness } & $\%$ & 100 & 100 & 91 \\
\hline & Value & 5 & 5 & 5 \\
\hline & Skor & 4 & 4 & 4 \\
\hline & Category & Excellent & Excellent & Excellent \\
\hline & $\mathrm{VxS}$ & 20 & 20 & 20 \\
\hline \multirow{5}{*}{$\begin{array}{l}\text { Coral Community } \\
\text { Coverage }\end{array}$} & $\%$ & 51 & 50 & 50,5 \\
\hline & Value & 5 & 5 & 5 \\
\hline & Score & 3 & 2 & 3 \\
\hline & Category & Good & Below Average & Good \\
\hline & $\mathrm{VxS}$ & 15 & 10 & 15 \\
\hline \multirow{5}{*}{ Life Form Type } & Total & 21 & 15 & 19 \\
\hline & Value & 4 & 4 & 4 \\
\hline & Score & 4 & 4 & 4 \\
\hline & Category & Excellent & Excellent & Excellent \\
\hline & VxS & 16 & 16 & 16 \\
\hline \multirow{5}{*}{ Coral Fish Species } & Total & 30 & 25 & 44 \\
\hline & Value & 4 & 4 & 4 \\
\hline & Score & 2 & 2 & 2 \\
\hline & Category & Below Average & Below Average & Below Average \\
\hline & VxS & 8 & 8 & 8 \\
\hline \multirow{5}{*}{ Current Velocity } & $\mathrm{cm} / \mathrm{s}$ & 38 & 19 & 20 \\
\hline & Value & 3 & 3 & 3 \\
\hline & Score & 2 & 3 & 3 \\
\hline & Category & Below Average & Good & Good \\
\hline & $\mathrm{VxS}$ & 6 & 9 & 9 \\
\hline \multirow{5}{*}{ Coral Reefs Depth } & Meter & 1,5 & 3 & 15 \\
\hline & Value & 3 & 3 & 3 \\
\hline & Score & 1 & 3 & 4 \\
\hline & Category & Poor & Good & Excellent \\
\hline & $\mathrm{VxS}$ & 3 & 9 & 12 \\
\hline \multicolumn{2}{|l|}{ VxS Total } & 68 & 72 & 80 \\
\hline \multicolumn{2}{|c|}{ Tourism Suitability Index (\%) } & 70,83 & 75 & 83,33 \\
\hline \multicolumn{2}{|c|}{ Category } & Conditionally Suitable & Conditionally Suitable & Suitable \\
\hline
\end{tabular}

Currently, the covering area of coral reefs are improving that is supported by continuous transplantation activities.

\section{Suitability of Diving Tour}

Parameters supporting the suitability of diving tour are similar to those of snorkeling tour parameters, except for the exclusion of reefs area and brightness level. This matter can be seen in the following table 4.

The suitable category for diving tour in location $C$ shows the success of coastal community incorporated in Samudera Bhakti fishermen community Wongsorejo. In contrast with the previous years in which the condition of coral reefs was severely damaged due to the use of potassium in fishing, which is not environmentally friendly, and the catching of ornamental fish. However, the changes in the community could change the environmental as well, especially in the Joint Protection Zone to be a beautiful underwater tourism area. This happens because the community agreed to transform the area to be a conservation.

The conditionally suitable category in station $A$ and $B$ is affected by several parameters. One of them is the condition of coral reefs coverage that is still in the recovery process (fish apartment construction and coral reefs transplantation) that affects the suitability of diving tour. In addition, the coast is quite shallow that makes it is not suitable for diving.

\section{Suitability of Snorkeling Tour}

Snorkeling tour has seven supporting parameters. Those parameters are water brightness, coral community coverage, coral growth, number of fish species, current velocity, depth, and coral reefs area, refer to table 5. 
Table 5. Marine Tourism Suitability Matrix in Snorkeling Tour Category of Bangsring Coast (Joint Protection Zone).

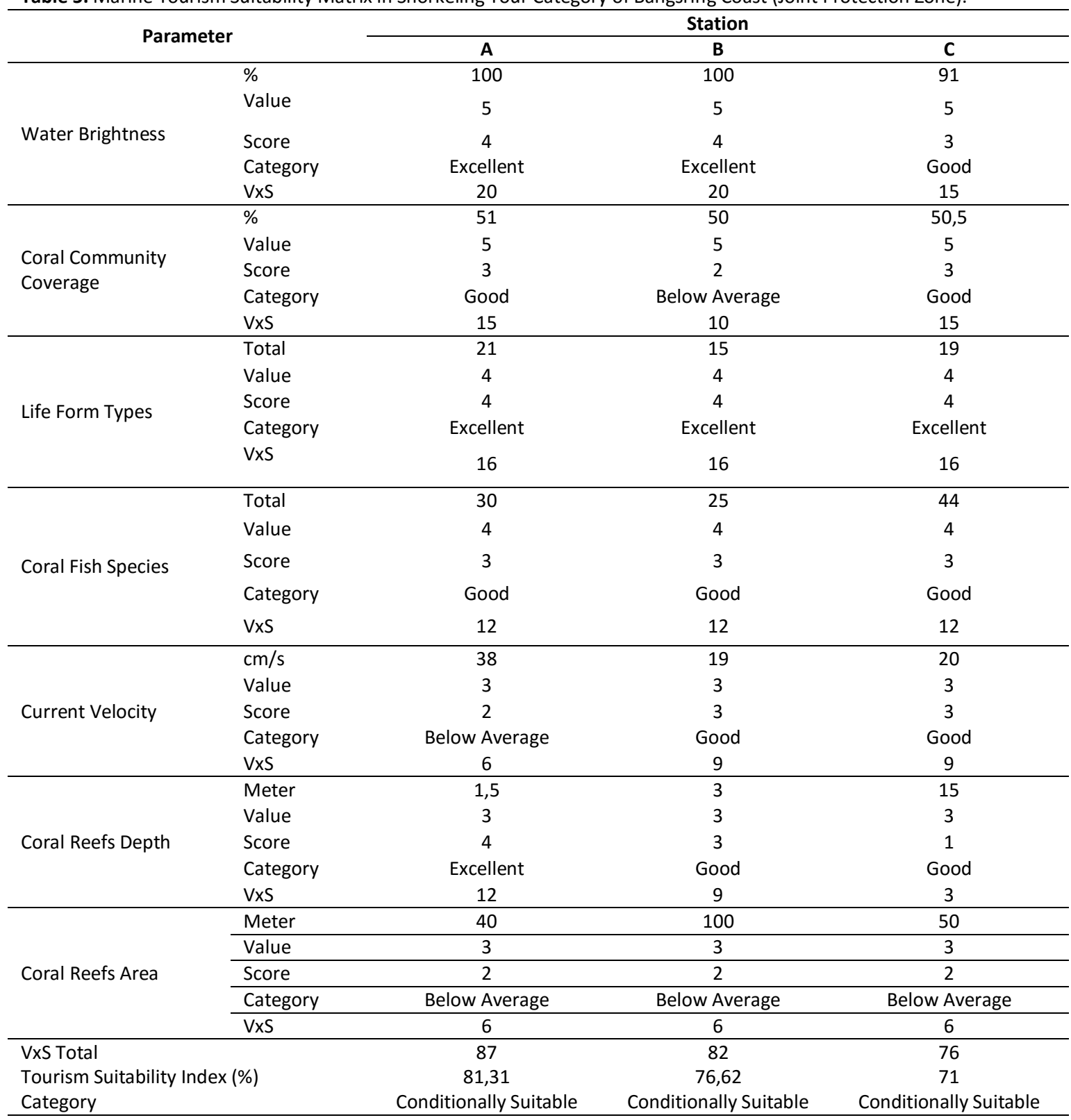

Overall, area and location for marine tourism in snorkeling category at Bangsring Coast (Joint Protection Zone) based on its suitability [10] all stations ( $A, B$, and $C$ ) are conditionally suitable with the area of $27,641 \mathrm{~m}^{2}$.

The Condition is affected by the low quality of coral community coverage since it is one of the parameters with high value. In addition, lack of coral community in station $A, B$, and $C$ resulted tourism suitability index in snorkeling tour reached only $83 \%$. Although station $\mathrm{A}$ and $\mathrm{C}$ showed good results, they still cannot support snorkeling tour activity. Therefore, station A, B, and $C$ need to improve the coral reefs' condition and increase the coverage above $75 \%$ to be suitable for snorkeling tour. Those improvement can be done by reef rehabilitation at all stations.

\section{Carrying Capacity Analysis}

Based on the analysis of Joint Protection Zone, the suitable area for tourism activity including diving and snorkeling is 11,954 and $84.179 \mathrm{~m}^{2}$ respectively. Based on that data, the carrying capacity for diving is only 6 people each day. While for snorkeling, the carrying capacity is up to 168 people each day. Further details can be seen in the following table6. 
Table 6. Calculation Results of Marine Carrying Capacity in the Joint Protection Zone.

\begin{tabular}{|c|c|c|c|}
\hline Tour & Area $\left(m^{2}\right)$ & Area $(\mathrm{Ha})$ & $\begin{array}{c}\text { CC } \\
\text { (people/day) }\end{array}$ \\
\hline Diving & 27.641 & 2,764 & 14 \\
\hline Snorkeling & 27.641 & 2,764 & 55 \\
\hline
\end{tabular}

In Bangsring Coast (Joint Protection Zone), there are around 20 people diving and up to 200 people snorkeling each day. That number already exceeded the carrying capacity in Bangsring Coast (Joint Protection Zone). Therefore, despite the popularity as tourist destination, it is suggested to arrange tourism visit that does not exceed the carrying capacity. The promotion can be optimally focused on the conservation activities to maintain the sustainability of the tourism area.

Tourism activities can reduce the quality of natural resources so that a sustainable management is required to maintain the balance of resources utilization. One of the balancing efforts is limiting the number of visitors. This limitation, hopefully, can minimize the damage on the coral community caused by tourism activities [11].

The population will always have an impact on the environment as time goes by. Hence, if the population, in this case the tourists, is not limited, it will threaten the coral reef conservation that carrying capacity will determine the sustainability of marine tourism activities [12].

An important factor that needs to be done in order to develop maritime tourism activities is the strategy and management of the attraction of the related tourism industry objects. Starting from the technical aspects, the service strategy reaches the bidding strategy. Other efforts are improving facilities and infrastructure, improving the quality of human resources in the field of marine tourism development, and providing appropriate tourism information systems and promotional programs. This industry is inseparable from threats both from within and from neighboring countries which have been considered as competitors that exploit, and security that has not been conducive also need special attention.

In addition, the development of maritime tourisms must be based on the existing guidelines or regulation. Because the efforts to control social, economic and cultural impacts must be a concern. The development of maritime tourism in this case should be focused on efforts to increase the distribution of opportunities, income, participation and responsibility of local communities that are integrated with the efforts of the government and the relevant business world in developing and managing the maritime resources environment. If the coastal and marine tourism sector is well managed, it is believed to be able to become an economic powerhouse and increase regional income.

One side of the potential for marine life is a gift for Indonesia which needs foreign exchange for the development of the nation and state. But on the other hand, it should be realized that economic development in general and the development of tourism in particular not only increases prosperity, and progress, but also raises changes to the environment and natural resources expected. Awareness of environmental impacts to face the development of marine tourism is very important in order to maintain the sustainability of the quality of the natural resource environment in particular, and ensure sustainable (economic) development in general [13].

Based on the description above, comprehensive management is the appropriate approach. Because it covers all aspects of the coral reef ecosystem, including biotic and abiotic environments. The governance approach involves all groups of people, including institutions and its rules. They are individuals, communities, governments, the private sector, and non-government institutions. As stakeholders, their goals, aspirations, expectations and obsession with the needs and existence of coral reefs must be achieved together. When there is a conflict of interest, the common goals are preferred. Conflict resolution in order to reach agreement is a governance mechanism.

The governance approach is built on the knowledge of coral reefs. General policies are taken and carried out based on scientific evidence and facts. Therefore, stakeholder aspirations that conflict with scientific facts need to be reconciled. The governance approach prioritizes sustainability, efficiency and productivity, and justice and equality. Biotic and abiotic elements, even including life inside and outside the ecosystem, are reasons or considerations in the formulation of sustainable use of ecosystem goods and services. The governance approach seeks to eliminate or reduce anthropogenic impacts (ecosystem damage due to human actions), and on the other 
hand does not carry out conservation management that harmonizes human interests and resource capacity [14].

\section{CONCLUSION}

Based on the analysis result, it can be concluded that:

a. Marine tourism area in the Bangsring Coast (Joint Protection Zone) is in a suitable condition for diving with area of 2,764 $\mathrm{Ha}$ and snorkeling with area of 2,764 $\mathrm{Ha}$.

b. Carrying capacity of marine tourism area in the Bangsring Coast (Joint Protection Zone) is 14 people/day for diving and 55 people/day for snorkeling.

\section{ACKNOWLEDGEMENT}

Thank you to the Ministry of Research, Technology and Higher Education, which has provided the opportunity to carry out Cooperative Research Higher Education 2018 Scheme.

\section{REFERENCES}

[1]. Baksir Abdurrachman, Fredinan Yulianda, T.F. Djamar Lumbatu, M.F. Rahardjo, 2009. Model Pengelolaan Ekowisata Pulau-Pulau Kecil Berkelanjutan Di Kecamatan Morotai Selatan Dan Morotai Selatan Barat Kabupaten Halmahera Utara, Propinsi Maluku Utara. Torani (Jurnal Ilmu Kelautan dan Perikanan ) Vol. 19 (1) April 2009: 1 - 8 ISSN: 0853-4489.

[2]. Dahuri, R., Ginting SP., Sitepu MJ. 2004. Pengelolaan Sumberdaya Wilayah Pesisir dan Lautan Secara Terpadu, Jakarta.

[3]. Hermantoro, H. 2009. Management of the Maritime Tourism Field in the Implementation of Adaptation Strategies to the Impacts of Climate Change. J. Kepariwisataan Indonesia. 4(1).

[4]. Adam, L. 2012. Sustainable fisheries development policy (case study: Wakatobi District, Southeast Sulawesi Province and Morotai Island District, North Maluku Province). Jurnal Perikanan dan Kelautan. 2(2): 115-126.

[5]. Itam, K.O., Etuk, E.A. \& Ukpong, I.G. 2014. Analysis of resource use efficiency among small-scale fish farms in Cross River State, Nigeria. Int. J. Fish. Aquacul. 6 (7):80-86.

[6]. Fauzi Y, Susilo B and Mayasari Z M 2009 Journal Forum Geografi, Vol. 23, No. 2. 101111.
[7]. Guyondet T, LA Comeau, B Cedric, J Grant, R Rosland, R Sonier and R Filgueira 2014 Climate Changes Influences Carrying Capacity in a Coastal Embayment Dedicated to Shellfish Aquaculture. Estuaries and Coasts, 38 (5): 1593-1618

[8]. Ayllon D, A Almodóvar, GG Nicola, I Parra and B Elvira 2012 Modelling Carrying Capacity Dynamics For The Conservation And Management Of Teritorial Salmonids Journal of Fisheries Research 134-136: 95103

[9]. Romimohtarto, Kasijan dan Sri Juwana, BIOLOGI LAUT Ilmu Pengetahuan tentang Biota Laut, Jakarta: Djambatan, 2009.

[10]. Yulianda F. 2007. Ekowisata Bahari sebagai Alternatif Pemanfaatan Sumberdaya Pesisir Berbasis Konservasi.Makalah Seminar Sains pada Departemen Manajemen Sumberdaya Perairan. Fakultas Perikanan dan IImu Kelautan IPB. Bogor.

[11]. Ketjulan, R., 2010, Daya Dukung Perairan Pulau Hari sebagai Objek Wisata Bahari, Paradigma, 14 (4), 195-204.

[12]. Bahar, A, dan Tambaru, R. 2010. Analisis Kesesuaian dan Daya Dukung Kawasan Wisata Bahari di Kabupaten Poliwari Mandar. Fakultas IImu Kelautan dan Perikanan UNHAS. Makassar.

[13]. Burhanuddin, 2011. The Spleeping Giant: Potensi dan Permasalahan Kelautan. Brilian Internasional, Surabaya.

[14]. Nikijuluw dkk, 2013.Coral Governance. IPB Press, Bogor. 